\title{
Transformation in Physico-chemical and Bioactive Constituents in Variable Grades of Kinnow Mandarin during Different Stages of Maturity
}

\author{
BVC Mahajan*, Swati Kapoor and Ritu Tandon \\ Punjab Horticultural Postharvest Technology Center, Punjab Agricultural University, India
}

Submission: January 02, 2018; Published: March 29, 2018

*Corresponding author: BVC Mahajan, Punjab Horticultural Postharvest Technology Center, Punjab Agricultural University, Ludhiana-141004, Punjab, India, Tel: +91-161-2405257; Email: mahajanbvc@gmail.com

\begin{abstract}
Harvesting time has a significant effect in determining the quality and postharvest shelf life of Kinnow mandarin fruit. Various physicochemical and bioactive components were assessed in kinnow fruit during different stages of maturity (November-March). Three different grades of kinnow fruit i.e. large, medium and small had TSS in the range of 9.74-11.06 percent and titratable acidity in the range of 0.68-0.96 percent. Maximum TSS content for all the three grades was found in the month of January. Titratable acidity decreased with progression of harvesting months with least value found in the month of March. TSS/acid ratio increased gradually during the harvesting months from November to March for all the grades of kinnow fruit. Highest TSS/acid ratio was noted in large kinnow fruits (16.00) and minimum in small fruits (13.36). Among the bioactive components, highest limonin content was observed in kinnow seeds $(2452.06 \mathrm{ppm})$ followed by kinnow peel $(80.40 \mathrm{ppm})$ and juice (18.06ppm). Carotenoid content of kinnow peel $(6.34 \mathrm{mg} \%)$ was higher than kinnow juice $(1.22 \mathrm{mg} \%)$. For different grades of kinnow fruit, maximum ascorbic acid (AA) content was observed in small fruits (26.58mg\%) followed by medium (25.36mg\%) and large fruits (22. 38mg\%). AA content was found in the range of $20.60-30.30 \mathrm{mg} \%$, with maximum value at early stage when fruits were immature followed by gradual decrease at the end of season. Juice recovery was found almost similar in all the three grades of kinnow fruit (41.94-42.98\%) with maximum juice content in November (48.20\%) and minimum in March (34.90\%). Highest pectin content was found in peel (2.14\%) followed by pomace $(1.56 \%)$ and juice $(0.40 \%)$
\end{abstract}

Keywords: Kinnow mandarin; Harvest time; Physico-chemical constituents; Bioactive compounds

\section{Introduction}

Among Citrus group, Kinnow (Citrus reticulata Blanco) is an important mandarin hybrid (Citrus nobilis x C. deliciosa) suited to North Indian conditions particularly in Punjab and the adjoining areas of Rajasthan and Himachal Pradesh states of India. Total area and production of citrus fruits in Punjab is 52 thousand hectares and 10.5 lakh metric tones respectively. Kinnow alone occupies more than sixty percent area among citrus fruits and is grown on an area of 49 thousand hectares and contributes 10 lakh metric tons of production annually [1]. Kinnow mandarin is quite important as it has a great variety of industrial and medicinal uses owing to its attractive colour and distinctive flavor. Kinnow is a nutritionally balanced fruit rich in vitamin $C$, vitamin $B$ and $\beta$-carotene [2]. It is a rich source of flavonoids with potential benefits to human health owing to its antiviral, antitoxic, anti-fungal, antibacterial, antiallergic, anti-inflammatory and antioxidant activities $[3,4]$.

In India, about 50 per cent of citrus fruit waste is generated in the form of peel, rag and seeds [5]. The citrus pulp/pomace contains 60-65 percent peel, 30-35 percent internal tissues and about 10 percent of seeds [6]. Citrus pulp and peel has been used widely for the production of essential oil [7], Kinnow peel is also a rich source of oil and d-limonene which finds its utility in perfumery and pharmaceutical/nonpharmaceutical industry. Citrus peels are used in marmalades as shreds and have been used as a raw material for pectin extraction [8]. Other pioneered products obtained from citrus waste include dietary fibers, bio-adsorbent, phytochemicals, gelling and stabilizer agents [9]. Citrus dietary fibre contains higher proportion of soluble components making it a better alternative for cereals. The dietary fibres are also associated with bioactive compounds like flavonoids and Vitamin $\mathrm{C}$ that promote several health benefits [10-12]. Limonin, among all limonoids is particularly responsible for development of delayed bitterness in citrus [13] and is found prominently in seeds. Limonin glucosides significantly decreased concentrations of four liver enzymes namely gamma-glutamyl transferase, alanine aminotransferase, alkaline phosphatase and complement component $\mathrm{C} 3$ which otherwise at elevated concentrations are associated with increased risk of chronic 
inflammatory disease such as metabolic syndrome, nonalcoholic fatty liver disease, type-2 diabetes mellitus, cardiovascular disease, chronic kidney disease and cancer [14].

The time of harvesting has a significant effect on external features of citrus fruit quality like fruit size, fruit weight, peel colour and internal characteristics like total soluble solids (TSS), titratable acidity (TA), TSS:TA ratio and post harvest life of fruit [15]. Bioactive compounds such as ascorbic acid, carotenoids, limonin are also affected by harvest time and help define antioxidant status of the fruit. As per Rokaya et al. [16] fruit weight, juice content, TSS followed increasing trends till mid November and then showed constant and decreasing trend. However, TA, firmness and vitamin C content showed decreasing trends with time. Stage of maturity is considered most important, as it determines storage-life and final fruit quality. Immature fruits are susceptible to mechanical damage and have inferior flavor quality whereas over mature fruits become mealy with insipid flavor. Fruits either picked too early or too late in their season are more susceptible to postharvest physiological disorders and less nutritive than the fruits picked at proper maturity [17]. Hence, certain maturity standards or indices must be followed while harvesting the fruits for maintaining postharvest quality of fruits. Kinnow fruit being a heavy bearer bears fruits of different sizes with variable physical and chemical properties. Different grades are used either for fresh consumption or for producing processed products depending upon their quality. Therefore, the present study was aimed to determine the periodic changes towards maturity in the physico-chemical quality characteristics of kinnow fruit with different grades.

\section{Materials and Methods}

\section{Fruit material}

Kinnow fruits were procured from Abohar region of Punjab from three different orchards in the months of November, December, January, February and March. The harvested fruits of different grades i.e., large, medium and small were brought every month and tested for different physico-chemical and nutritional attributes.

\section{Physico-chemical constituents}

Kinnow fruits of three different grades i.e. large, medium and small were assessed for physico-chemical parameters such as Total soluble solids (TSS), titratable acidity (\%), TSS: Acid and Juice recovery (\%) as per standard procedures. TSS was recorded using hand refractometer (Erma, Japan). The acidity of fruits was estimated by titrating the known quantity of juice against $\mathrm{N} / 10 \mathrm{NaOH}$ and was expressed as percentage citric acid [18]. Juice recovery was calculated after extracting the juice with the help of screw type extractor with sieve 18 mesh sizes.

\section{Bioactive constituents}

Kinnow fruit being a rich source of bioactive constituents was tested for ascorbic acid content by titrating the known quantity of juice against $0.04 \%$ 2,6-dichlorophenolindophenol dye and expressed in percent [18]. The limonin content of juice, peel and seed irrespective of size was estimated by extracting the known quantity of sample with petroleum ether, chloroform and distilled water. The final solution was prepared by adding Burnham's reagent and the observations were recorded with UV-VIS spectrophotometer at $503 \mathrm{~nm}$ and expressed as ppm [19]. Carotenoids were estimated by extracting the known quantity of sample with 2:3 Acetone: Petroleum ether solution. Then the reading of colour was taken at $452 \mathrm{~nm}$ by using UV-VIS spectrophotometer for final estimation of total carotenoids and expressed as mg (\%) [18]. Pectin content was estimated using standard procedure where pectin was sponified with alkali and precipitated as calcium pectate from an acidifed solution by the addition of calcium chloride. The calcium pectate precipitates were filtered, washed, made free from chloride, dried and weighed [18].

\section{Results and Discussion}

\section{Physico-chemical constituents}

Among the different size grades, small fruits were noted to have higher TSS followed by medium and large varieties, respectively. However, irrespective of size grade, the TSS content of fruits increased up to January and then declined gradually till March (Table 1). TSS content increased as fruits mature which may be due to accumulation of more sugars into the fruits through hydrolysis of starch [20]. The highest acidity was observed in small fruits, followed by medium and than large fruits, which decreased with advancement of maturity in fruits (Table 1). The decrease in acidity was gradual till January but later decreased at a sharpening rate. Acid contents are known to decrease with increase in maturity of the fruit. Decrease in acid content could also be attributed to utilization of acids in the fruit respiratory process [21]. The TSS: acidity ratio showed an increasing trend with the development of fruit in all the three grades. The maximum ratio was observed in large size and minimum in small size fruits. Mukhim et al. [22] discussed similar findings that the TSS: acidity ratio decreased significantly with increasing fruit growth and development. Transfer of natural carbohydrate from leaves to fruit during maturation could also explain increasing TSS: acidity ratio [23]. Advancement of ripening decreased the juice percent in kinnow fruits as the maximum juice recovery of $48.2 \%$ was measured in November, which lowered to $34.9 \%$ in March (Figure 1). Decrease in juice content with progression of maturity stage might be due to catabolism activities in fruit [17]. 
Table 1: Effect of harvesting time on physico-chemical attributes of kinnow fruit.

\begin{tabular}{|c|c|c|c|c|c|c|c|c|c|}
\hline \multirow[t]{2}{*}{ Date } & \multicolumn{3}{|c|}{ Large } & \multicolumn{3}{|c|}{ Medium } & \multicolumn{3}{|c|}{ Small } \\
\hline & TSS & Acidity & $\begin{array}{c}\text { TSS: } \\
\text { Acidity }\end{array}$ & TSS & Acidity & $\begin{array}{c}\text { TSS: } \\
\text { Acidity }\end{array}$ & TSS & Acidity & $\begin{array}{c}\text { TSS: } \\
\text { Acidity }\end{array}$ \\
\hline Nov & $9.3 \pm 0.10$ & $1.0 \pm 0.06$ & $9.3 \pm 0.32$ & $9.2 \pm 0.17$ & $1.2 \pm 0.12$ & $7.7 \pm 0.15$ & $9.5 \pm 0.12$ & $1.4 \pm 0.15$ & $6.8 \pm 0.10$ \\
\hline Dec & $10.4 \pm 0.26$ & $0.9 \pm 0.12$ & $11.6 \pm 0.40$ & $11.5 \pm 0.12$ & $1.2 \pm 0.10$ & $9.6 \pm 0.17$ & $12.4 \pm 0.15$ & $1.3 \pm 0.06$ & $9.5 \pm 0.12$ \\
\hline Jan & $10.8 \pm 0.15$ & $0.6 \pm 0.56$ & $18.0 \pm 0.12$ & $11.9 \pm 0.26$ & $0.8 \pm 0.10$ & $14.9 \pm 0.36$ & $12.7 \pm 0.4$ & $1.0 \pm 0.06$ & $12.7 \pm 0.31$ \\
\hline $\mathrm{Feb}$ & $9.2 \pm 0.21$ & $0.5 \pm 0.06$ & $18.4 \pm 0.15$ & $10.1 \pm 0.12$ & $0.5 \pm 0.06$ & $20.2 \pm 0.21$ & $10.9 \pm 0.31$ & $0.6 \pm 0.15$ & $18.2 \pm 0.21$ \\
\hline March & $9.0 \pm 0.19$ & $0.4 \pm 0.19$ & $22.5 \pm 0.23$ & $9.9 \pm 017$ & $0.5 \pm 0.14$ & $19.8 \pm 0.57$ & $9.8 \pm 0.17$ & $0.5 \pm 0.06$ & $19.6 \pm 0.83$ \\
\hline Mean & 9.74 & 0.68 & 16 & 10.56 & 0.84 & 14.44 & 11.06 & 0.96 & 13.36 \\
\hline
\end{tabular}

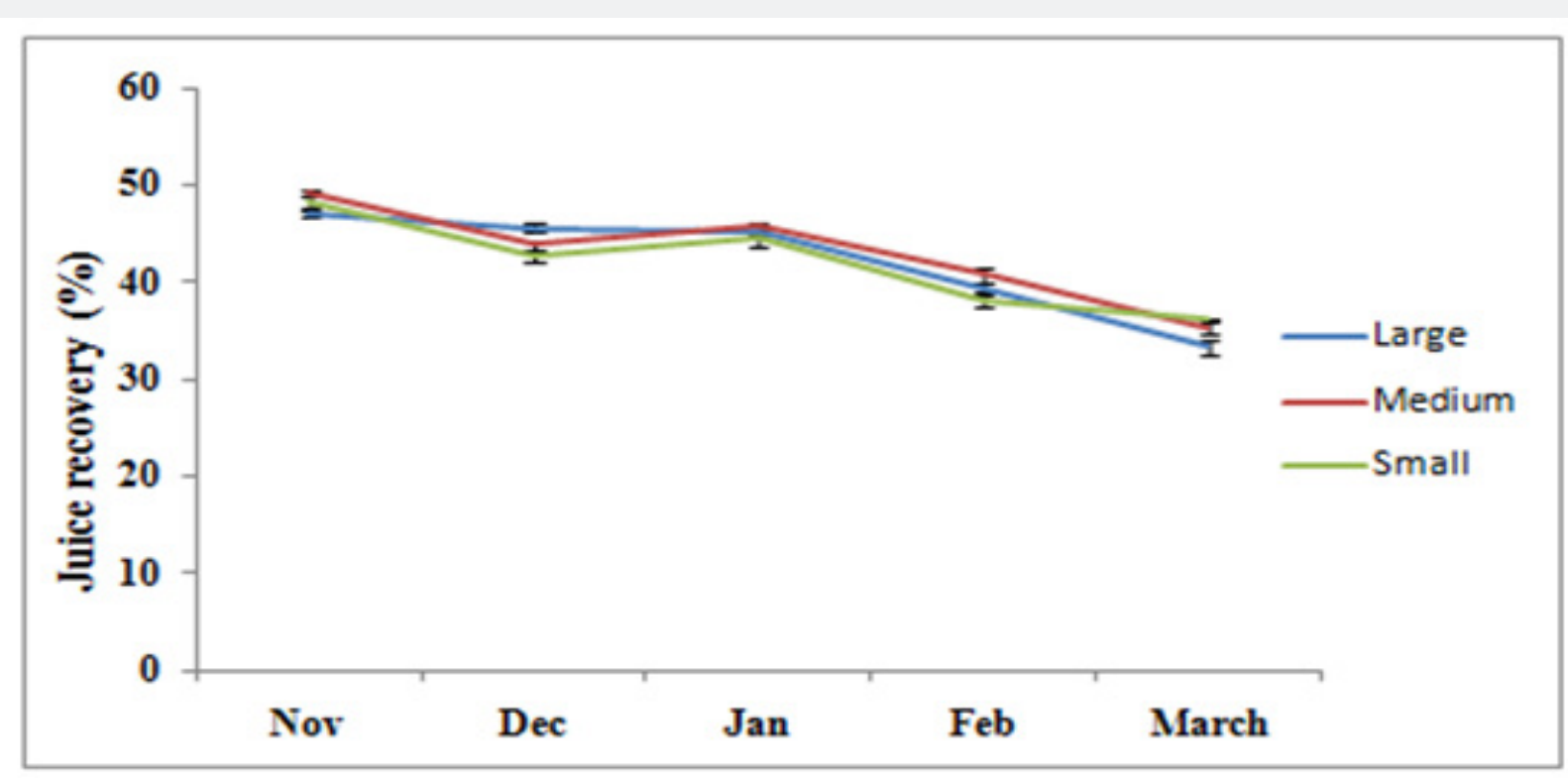

Figure 1: Effect of harvesting time on juice recovery (\%) of kinnow fruits.

\section{Bioactive constituents}

The highest limonin contents were found in seed (2452.0ppm) followed by peel $(80.4 \mathrm{ppm})$ and lowest in juice (15.5ppm). It was examined that the limonin content was maximum during December harvest in all the three parts of the fruit viz. seed, peel and juice. The content decreased later but without any significant trend (Table 2). Combariza et al. [24] stated that the limonene concentration of lemon reached a maximum level of $79.4 \%$ when the fruit was in the intermediate maturation stage characterized by greenish-yellow coloration. The pectin percent of kinnow juice decreased sharply from November to March, whereas it remains almost constant in peel and pomace (Table 2). Kinnow peel contained highest pectin $(2.12 \%)$ followed by pomace (1.62\%). Mukhim et al. [25] reported that the pectin content of Assam lemon increased initially from 1.36 to $3.07 \%$ up to certain period (30 up to 60 DAF) and thereafter declined with advancement of growth and development $(0.89 \%$ at $150 \mathrm{DAF})$. Increase in pectin 
content during fruit development might be due to conversion of protopectin into water-soluble forms of pectin and decrease of pectin in later stages could be due to enzymatic degradation of pectin. Kinnow fruit is a rich source of carotene as high temperatures promote synthesis of carotenoids in tropical fruit crops [26]. The carotene content of kinnow increased till January and than decreased up till March (Table 2). Peel of kinnow contained comparatively higher (6.34\%) amount of carotene than juice (1.22\%). Ascorbic acid content usually has uneven distribution in fruit tissues that varies with the fruit development stage [27]. The ascorbic acid content increased till December $(30.3 \mathrm{mg} / 100 \mathrm{~g})$ and thereafter showed a declining trend till March (Figure 2). Early harvest or mid harvest fruits of oranges, tangarines and grape fruit had higher ascorbic acid content than late season crop [28]. Losses in ascorbic acid may be due to its sensitivity to oxidation at high temperature [29]. Nagy [30] also reported that ascorbic acid concentration decrease upon fruit maturation and ripening.

Table 2: Effect of harvesting time on bioactive components of kinnow fruit.

\begin{tabular}{|c|c|c|c|c|c|c|c|c|}
\hline \multirow{2}{*}{ Date } & \multicolumn{3}{|c|}{ Limonin (ppm) } & \multicolumn{3}{c|}{ Pectin \% } & Carotene mg (\%) \\
\hline & Juice & Seed & Peel & Juice & Peel & Pomace & Juice \\
\hline Nov & $22.1 \pm 0.15$ & $1639.9 \pm 2.10$ & $77.7 \pm 0.92$ & $0.8 \pm 0.06$ & $2.2 \pm 0.17$ & $1.8 \pm 0.11$ & $0.9 \pm 0.10$ & $4.2 \pm 0.15$ \\
\hline Dec & $29.3 \pm 0.26$ & $3344.2 \pm 1.80$ & $125.4 \pm 0.66$ & $0.4 \pm 0.06$ & $2.1 \pm 0.21$ & $1.7 \pm 0.15$ & $1.2 \pm 0.12$ & $6.9 \pm 0.46$ \\
\hline Jan & $17.8 \pm 0.35$ & $1728.0 \pm 3.72$ & $63.7 \pm 0.40$ & $0.3 \pm 0.03$ & $2.3 \pm 0.10$ & $1.5 \pm 0.10$ & $1.6 \pm 0.15$ & $8.3 \pm 0.15$ \\
\hline Feb & $11.1 \pm 0.29$ & $2969.9 \pm 1.21$ & $104.5 \pm 2.1$ & $0.3 \pm 0.03$ & $2.1 \pm 0.13$ & $1.4 \pm 0.12$ & $1.1 \pm 0.15$ & $7.2 \pm 0.21$ \\
\hline March & $10.0 \pm 0.31$ & $2578.3 \pm 2.18$ & $30.7 \pm 0.20$ & $0.2 \pm 0.01$ & $2.0 \pm 0.11$ & $1.4 \pm 0.23$ & $1.3 \pm 0.06$ & $5.1 \pm 0.29$ \\
\hline Mean & 18.06 & 2452.06 & 80.4 & 0.4 & 2.14 & 1.56 & 1.22 & 6.34 \\
\hline
\end{tabular}

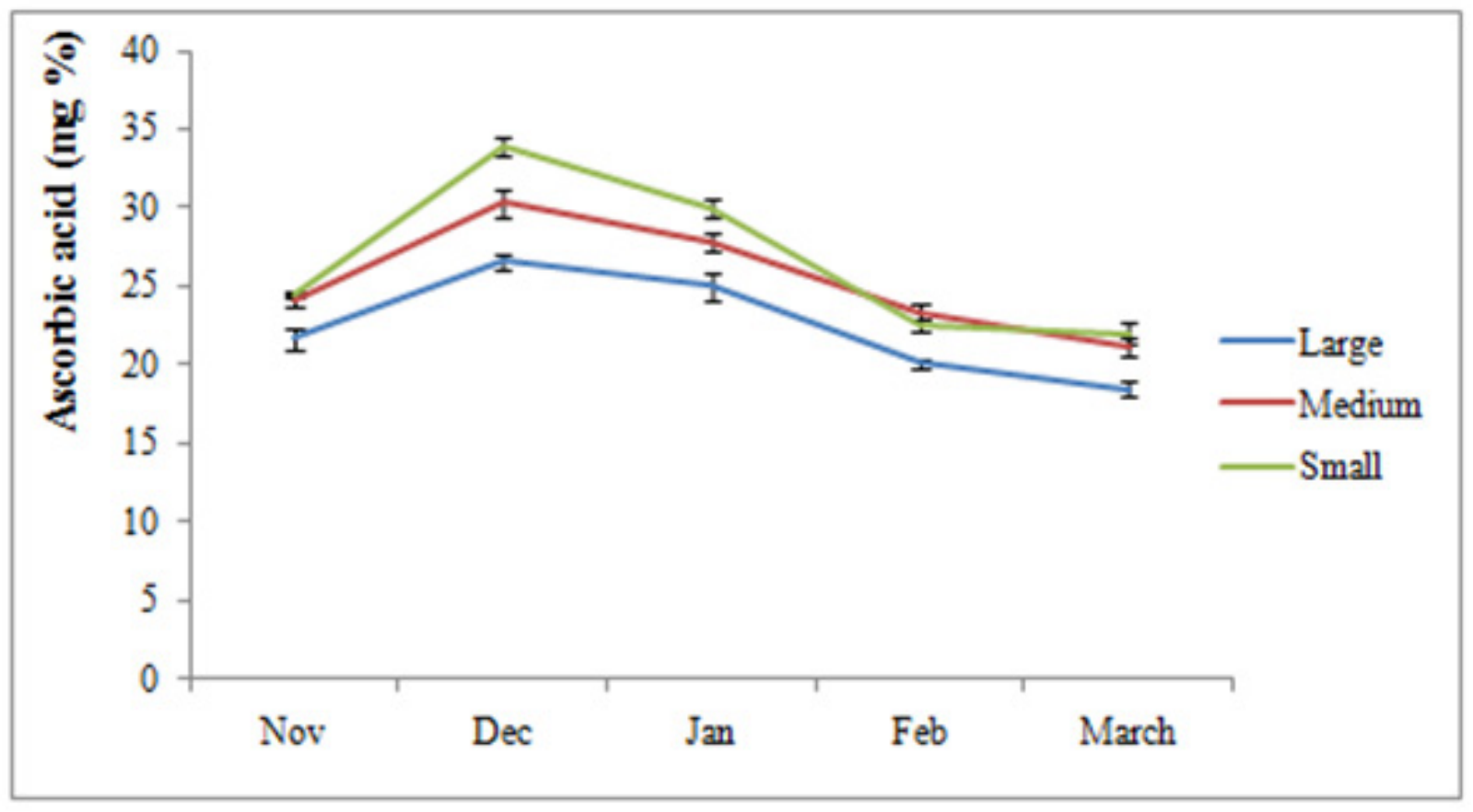

Figure 2: Effect of harvesting time on ascorbic acid content (\%) of kinnow fruits. 


\section{Conclusion}

Kinnow fruits attained more TSS during the month of January as compared to other months. The acidity of the fruit declined gradually during growth and maturation period. TSS/ acid ratio of the fruit increased upto February and thereafter declined. However, the optimum level of TSS/acid ratio was found in the month of February. It was noticed that small grade fruit have higher ascorbic acid content than medium and large grade. The juice yield declined during fruit development process and ranged between $32-48 \mathrm{mg} \%$. The pectin of juice was found to be highest in the beginning of harvesting season and thereafter declined sharply. On an average carotene content of juice ranged between 0.89 to $1.2 \%$ and that of peel ranged between 4.85 to $6.69 \%$. Overall it can be concluded that kinnow mandarin fruit is best suited for harvest during mid January till February.

\section{References}

1. Anonymous (2016) Indian Horticulture Database.

2. Kelebek H, Canbas C, Selli S (2008) Determination of phenolic composition and antioxidant capacity of blood orange juices obtained from cvs. Moro and Sanguinello (Citrus sinensis (L.) Osbeck) grown in Turkey. Food Chem 107(4): 1710-1716.

3. Diankov S, Karsheva M, Hinkov I (2011) Extraction of natural antioxidants from lemon peels: Kinetics and antioxidant capacity. J Univ Chem Technol Metallurgy 46(3): 315-319.

4. Prashar S, Sharma H, Garg M (2014) Antimicrobial and antioxidant activities of fruits and vegetables peels: A review. J Pharmacogn Phytochem 3(1): 160-164.

5. Rudra SG, Nishad J, Jakhar N, Kaur C (2015) Food industry waste: mine of nutraceuticals. Int J Sci Environ Technol 4(1): 205-229.

6. Crawshaw R (2004) Co-product Feeds: Animal Feeds from the Food and Drinks Industries. Nottingham University Press, England, pp. 285.

7. Izquierdo L, Sendra JM (2003) Citrus Fruit composition and characterization. In: Encyclopedia of food sciences and nutrition, B Caballero, et al. (Eds.), Oxford Academic Press, England, UK pp. 6000.

8. Mamma D, Kourtoglou E, Christakopoulos P (2008) Fungal multienzyme production on industrial by-products of the citrus-processing industry. Bioresource Technol 99: 2373-2383.

9. Henn T, Kunz B (1996) Use of plant pomace for manufacture of functional drinks. Fluessiges Obst 63(12): 715-719.

10. Gorinstein S, Martin-Belloso O, Park YS, Haruenkit R, Lojek A, et al. (2001) Comparison of some biochemical characteristics of different citrus fruits. Food Chem 74: 309-315.

11. Marın FR, Frutos MJ, Perez-Alvarez JA, Martınez-Sanchez F, Del Rıo JA (2002) Flavonoids as nutraceuticals; structural related antioxidant propertiies and their role on ascorbic acid preservation. Stud Natur Prod Chem 26(G): 741-778.

12. Callaway TR, Carroll JA, Arthington JD, Edrington TS, Rossman ML, et al. (2011) Escherichia coli 0157:H7 populations in ruminants can be reduced by orange peel product feeding. J Food Protect 74(11): 19171921.
13. Maier VP, Bennett RD, Hasegawa S (1977) Limonin and other limonoids. In: Citrus Science and technology. In: Nagy S, et al. (Eds.), Washington, DC: American Chemical Society, USA, pp. 355-396.

14. Kelley DS, Adkins YC, Zunino SJ, Woodhouse LR, Bonnel EL, et al. (2015) Citrus limonin glucoside supplementation decreased biomarkers of liver disease and inflammation in overweight human adults. J Funct Foods 12: 271-281.

15. Iqbal M, Khan MN, Zafar M, Munir M (2012) Effect of harvesting date on fruit size, fruit weight and total soluble solids of Feutrell's Early and Kinnow cultivars of mandarin. Sarhad J Agri 28(1): 19-21.

16. Rokaya PR, Baral DR, Gautam DM, Shrestha AK, Pandyal KP (2016) Effect of altitude and maturity stages on quality attributes of mandarin (Citrus reticulate Blanco.). Am J Plant Sci 9: 66-135.

17. Riaz M, Zamir T, Rashid N, Jamil N, Masood Z, et al. (2015) Comparative study of nutritional quality of orange at different maturity stages in relation to significance for human health. American-Eurasian Journal of Toxicological Sciences 7(4): 209-213.

18. Ranganna S (1997) Handbook of analysis and quality control for fruit and vegetable products. Tata Mc Graw Hill Pub Co. Ltd. New Delhi, India.

19. Vaks B, Lifshitz A (1981) Debittering of orange juice by bacteria which degrade limonin. J Agric Food Chem 29(6): 1258-1261.

20. Hossain MM, Paul DK, Rahim MA (2016) Physico-chemical changes during growth and development of sapota fruit. Turkish J Agric Natural Sci 3(1): 58-64

21. Nagar PK (1993) Effect of some ripening retardants on fruit softening enzymes of kinnow mandarin fruits. Indian J Plant Physio 37: 122.

22. Mukhim C, Nath A, Dekha BC, Swer TL (2015) Changes in physicochemical properties of Assam lemon (Citrus limon Burm.) at different stages of fruit growth and development. The Bioscan 10(2): 535-537.

23. Drogoudi PD, Pantelidis G (2011) Effects of position on canopy and harvest time on fruit physico-chemical and antioxidant properties in different apple cultivars. Scientia Horticulturae 129(4): 752-760.

24. Combariza MY, Tirado CB, Stashenko E, Shibamoto T (1994) Limonene concentration in lemon (Citrus volkameriana) peel oil as a function of ripeness. J High Resolut Chromatogr 17(9): 643-646.

25. Mukhim C, Nath A, Swer TL, Ghosh B (2016) Changes in pectin and total chlorophyll content Assam lemon (Citrus limon Burm.) peel during fruit growth and development. Environment and Ecology 34(4A): 1477-1479.

26. Rodriguez-Amaya DB, Kimura M (2004) Harvest Plus handbook for carotenoid analysis; Harvestplus Technical Monograph 2. Washington DC. and Cali, Columbia, USA, p. 3.

27. Yang XY, Xie JX, Wang FF, Zhong J, Liu YZ, et al. (2011) Comparison of ascorbate metabolism in fruits of two citrus species withobvious difference in ascorbate content in pulp. J Plant Physiol 168(18): 21962205.

28. Ladaniya MS (2008) Nutritive and medicinal value of citrus fruit. In: Citrus Fruit: Biology Technology and Evaluation, In: MS Ladaniya (Eds.), Elsevier Inc., USA, pp. 501-514.

29. Njoku PC, Ayuk AA, Okoye CV (2011) Temperature effects on vitamin C content in citrus fruits. Pak J Nutr 10(12): 1168-1169.

30. Nagy S (1980) Vitamin C contents of citrus fruit and their products: a review. J Agric Food Chem 28: 8-18. 
This work is licensed under Creative Commons Attribution 4.0 License DOI: 10.19080/NFSIJ.2018.06.555679

\section{Your next submission with Juniper Publishers} will reach you the below assets

- Quality Editorial service

- Swift Peer Review

- Reprints availability

- E-prints Service

- Manuscript Podcast for convenient understanding

- Global attainment for your research

- Manuscript accessibility in different formats

( Pdf, E-pub, Full Text, Audio)

- Unceasing customer service

Track the below URL for one-step submission https://juniperpublishers.com/online-submission.php 